\title{
Nitrogen Blanketing and Hydrogen Starvation in Dead-Ended-Anode Polymer Electrolyte Fuel Cells Revealed by Hydro-Electro-Thermal Analysis
}

\author{
Quentin Meyer ${ }^{1}$, Sean Ashton², Sergio Torija ${ }^{2}$, Chris Gurney², Pierre Boillat ${ }^{3,4}$, \\ Magali Cochet ${ }^{3}$, Erik Engebretsen ${ }^{1}$, Donal P. Finegan ${ }^{1}$, Paul Adcock², Paul R. \\ Shearing ${ }^{*}$, Dan J. L. Brett ${ }^{* 1}$
}

'Electrochemical Innovation Lab, Department of Chemical Engineering, UCL, London, WC1E 7JE, United Kingdom.

2Intelligent Energy, Charnwood Building Holywell Park, Ashby Road, Loughborough Leicestershire, LE11 3GB, United Kingdom.

${ }^{3}$ Electrochemistry Laboratory (LEC), Paul Scherrer Institute (PSI), 5232 Villigen, Switzerland.

${ }^{4}$ Neutron Imaging and Activation Group (NIAG), Paul Scherrer Institute (PSI), 5232 Villigen, Switzerland.

* Author to whom correspondence should be addressed

Tel.: +44(0)20 76793310

Web: www.ucl.ac.uk/electrochemical-innovation-lab

Email: d.brett@ucl.ac.uk; p.shearing@ucl.ac.uk 


\section{Abstract}

Dead-ended anode operation has a number of practical advantages that simplify system complexity and lower cost for polymer electrolyte fuel cells. However, deadended mode leads to performance loss over time which can only be reversed by performing intermittent purge events. This work applies a combined hydro-electrothermal analysis to an air-cooled open-cathode fuel cell, presenting experimental functional maps of water distribution, current density and temperature. This approach has allowed the identification of a 'nitrogen blanketing' effect due to nitrogen crossover from the cathode and a 'bypass' effect where a peripheral gap between the gasket and the GDL offers a hydrogen flow 'short circuit' to the border of the electrode. A consequence of high local current density at the margin of the electrode, and resulting high temperatures, may impact the lifetime of the cell in dead-end mode.

\section{Keywords}

Dead-ended anode; bypass effect; neutron imaging; nitrogen blanketing; current and temperature mapping.

\subsection{Introduction}

Polymer electrolyte fuel cells (PEFC) fuelled with hydrogen are among the most promising energy conversion technologies for a broad range of applications, including portable, stationary and automotive power delivery. Dead-ended anode operation enables significant design simplification, with the replacement of humidifiers, and flow controllers by pressure regulators [1]. However, it causes 
reversible performance decay, and intermittent purging of the anode chamber is required to sustain effective operation. Greater insight into the mechanism of fuel cell operation during dead-ended mode is required in order to optimise the purging programme and ensure that irreversible degradation does not result. In-situ diagnostic techniques provide one of the most effective ways of studying the performance of fuel cells; combined mapping of current density, temperature and water distribution is applied here to give an unprecedented level of understanding into dead-ended fuel cell operation.

\subsection{Current and temperature mapping in fuel cells}

Initiated by Cleghorn et al. [2] and Brett et al. [3] over 15 years ago, current mapping in polymer electrolyte fuel cells have provided great insight into fuel cell operation. The technique has identified a range of current density distribution profiles associated with factors such as: uneven fuel consumptions [3-6], operating conditions [7-9], stoichiometric ratios [10-13], reactant flow orientation [5,9], and water management issues [14].

Temperature distribution has also been extensively investigated, identifying areas of higher electrochemical activity, hot-spot formation and fuel depletion. Thermocouples can provide a crude measure of temperature inside fuel cells [15-18], but cannot provide high spatial resolution, and as they need to be inserted inside the fuel cell, this often requires design modifications which may affect reactant flow and fuel cell performance. Infrared thermal imaging can provide very high spatial and temperature resolution [19-24], but requires use of modified fuel cells with an infrared transparent window, and/or cells with open channels (such as open-cathode fuel cells [25-28]) or can only image the outer surface of a cell or stack $[29,30]$. 
Combined temperature and current mapping studies allow the impact and interactions of these two parameters on the overall performance to be assessed $[17,20,31-33]$. However, capturing the water content may provide insights on how the temperature and current density fluctuate, and therefore should ideally be measured at unison.

\subsection{Neutron imaging in fuel cells}

Neutron imaging can identify water in the in-plane orientation (with the membrane plane parallel to the beam) and through-plane orientation (with the membrane plane perpendicular to the beam), enabling differentiation of water content in the cathode and the anode [34-36], the effect of different cell designs [37], and operating conditions on the water distribution throughout the cells [38-53]. Neutron imaging has been combined with other modelling and experimental techniques, such as current mapping [54], CFD model validation [38,53,55], optical imaging [56], neutron scattering [49] and localised EIS [45]. The authors have recently combined neutron imaging with current and temperature mapping in a single device [57], linking water formation / evaporation with current density and temperature under steady state conditions.

\subsection{Dead-ended anode operations in an air-cooled open cathode fuel cell.}

Dead-ended anode operation is a common mode for operating fuel cells as it can simplify the fuel cell system, potentially avoiding flow meters, humidifiers, and drastically reducing hydrogen losses (slippage). It employs a single pressure regulator before the hydrogen inlet to the stack and a purge valve after the anode outlet [1]. However, dead-ended anode operation leads to a gradual voltage loss; therefore, a purge valve is intermittently opened at regular intervals, leading to instantaneous recovery of cell voltage / stack voltages. This gradual voltage loss has 
been measured and modelled [58-62], highlighting the influence of several factors. Nitrogen cross-over from the cathode to the anode, across the electrolyte membrane, has been reported to have a significant influence [60,63], which has been confirmed by controlling the nitrogen-to-hydrogen ratio at the anode inlet [64]. The extent of $\mathrm{N}_{2}$ crossover from cathode to anode (the permeation factor) is of particular relevance for dead-ended operation and has been shown to increase with increasing current density and temperature $[63,65]$. Water management has been studied using neutron imaging [37,42], and by the application of a transparent cell [66], highlighting water accumulation towards the exhaust of the cell. However, these studies both used humidified cathodes; therefore, the reported water accumulation is caused by back diffusion from the cathode to the anode, leading to accumulation and flooding.

The stack used in this study is an air-cooled, open-cathode fuel cell, operated with dry fuel and oxidant. Unlike passive air-breathing systems typically limited to a maximum current density of $\sim 0.6 \mathrm{~A} \mathrm{~cm}^{-2}$ due to heat and water management issues [67-72], in the 'air-cooled, open-cathode' configuration, air is forced through the cathode channels using fans, which improves performance and enables higher current densities to be attained [73-77]. In air-cooled, open-cathode systems the temperature depends on the voltage and current density $[67,78]$, air cooling flow rate $[73,76]$, and heat transfer characteristics of the stack. In practice, the temperature management is normally performed using a single-point thermocouple inserted in the centre of the cell $[18,29,75]$, or for development work using multiple microthermocouple measurements at various locations in the fuel cell $[15,79,80]$.

The authors have previously studied dead-ended operation, on a cell with dry fuel and air, using techniques such as mass spectrometry (revealing nitrogen 
accumulation), thermal imaging and electrochemical impedance spectroscopy [29], as well as combined current and temperature mapping, revealing large gradients between the fuel inlet and exhaust [33].

Here, we present the results obtained by applying the recently developed hydroelectro-thermal analysis [57] technique to an air-cooled, open-cathode fuel cell operated in dead-ended anode mode, to capture dynamic operation, combining current and temperature mapping with water mapping during dead-ended operation.

\section{Experimental}

\section{Current and temperature mapping}

Current and temperature mapping were performed using a 16-segment printed circuit board sensor plate, with a $4 \mathrm{~cm}^{2}$ resolution, recording every $0.5 \mathrm{~s}\left(\mathrm{~S}_{++}\right.$ Simulation Services, Germany), described previously [57].

The sensor plate was imaged at the NEUTRA beam line of the SINQ neutron source (NEUTRA, Paul Scherrer Institut, Villigen, Switzerland) prior to its insertion in the stack and was found to be $80 \%$ transparent to the beamline neutron spectrum, which is suitable for neutron imaging. Therefore, the combined neutron imaging and current and temperature mapping is possible with this choice of hardware. The sensor plate is inserted between the first and the second cell, to measure the average current and temperature distribution of both cells.

Fuel cell testing - A 2-cell (60 $\mathrm{cm}^{2}$ active area) air-cooled / air-breathing fuel cell stack was used for testing (Intelligent Energy Ltd., UK). The membrane electrode assembly was composed of commercially available gas diffusion layers (GDLs) and catalyst coated membrane (CCM) with Pt loading of 0.1 and $0.4 \mathrm{mg} \mathrm{cm}^{-2}$ on the anode and cathode, respectively. 
The test station [29] supplied dry hydrogen (99.995\%) at ambient temperature to the anodes and air was forced through the stack using a single fan (SanAce 36, Sanyo Denki) to the open-cathode channels. The exhaust hydrogen flow rate in throughflow mode was measured using a thermal mass flow meter (MassVIEW, Bronkhorst) to be 4.7 SLPM, which ensures a stoichiometric ratio of 2 at $1 \mathrm{~A} \mathrm{~cm}^{-2}$. The fans, which provide cooling and air supply to the cathode, were controlled by a programmable power supply (3649A Agilent). The current drawn from the PEFC was controlled using an electronic load (PLZ664WA, Kikusui) in galvanostatic mode. An in-house computer controlled system controls the air, hydrogen, cooling and electrical valves (LabVIEW, National Instruments) as well as recording and presenting data using a data acquisition card (USB 6363, National Instruments). Ambient temperature, pressure (absolute) and relative humidity $(\mathrm{RH})$ were measured at $25{ }^{\circ} \mathrm{C} \pm 0.2{ }^{\circ} \mathrm{C}, 0.97 \pm 0.02$ bar and $40 \% \mathrm{RH}$ respectively, during all tests. The operation of this fuel cell in terms of cathode design, cooling and active channels and materials, has been described in previous reports $[29,30]$, and is summarised in Figure 1. The cathode is operated in through-flow mode, with an air flow rate of $4 \times$ $10^{-3} \mathrm{~m}^{3} \mathrm{~s}^{-1}$. 


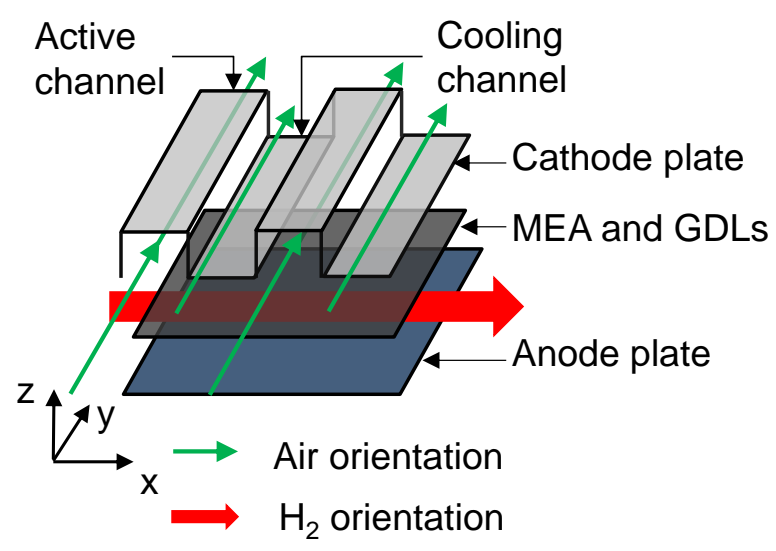

Figure 1. Not up to scale illustration of the two active and cooling channels of the cell, showing the air and hydrogen orientation, along with the cathode active and cooling channels. Hydrogen flows laterally through the anode GDL from inlet to outlet.

\section{Neutron imaging}

Neutron radiography was performed at the neutron imaging facility NEUTRA of the SINQ spallation source (Paul Scherrer Institut, Switzerland) [81]. Thermal neutrons provided by the source are extracted from a moderator tank in the thermal energy range of $1 \times 10^{-3}$ to $10 \mathrm{eV}$ with a Maxwellian spectrum energy of $25 \times 10^{-3} \mathrm{eV}$. The setup for neutron imaging has been described previously [57]. The cell is imaged in through-plane orientation.

Quantification of the water thickness from neutron images

All the materials of the cell contribute to the attenuation of the transmitted neutron beam, following the Beer-Lambert law (Equation 1).

$I / I_{0}=\exp \left(-\mu_{\text {water }} t_{\text {water }}\right)$

With I the intensity of the beam in operation, $I_{0}$ the intensity of the beam for the dry cell (without water), $\mu_{\text {water }}$ the attenuation coefficient of water, $t_{\text {water }}$ the thickness of 
water. $I$ and $I_{0}$ are determined after all necessary corrections (filtering, subtraction of background components, alignment of "working" and reference images) [82].

The water thickness is then extracted by taking the logarithm, divided by the attenuation coefficient $\mu_{\text {water }}$.

$t_{\text {water }}=-\frac{\ln \left(I / I_{o}\right)}{\mu_{\text {water }}}$

In this case, $\mu_{\text {water }}$, the attenuation coefficient of neutrons in liquid water, was measured in the NEUTRA beamline for the given setup at $3.5 \mathrm{~cm}^{-1}$ [83]. In the following sections, the water content will be expressed as the effective water thickness in $\mu \mathrm{m}$. A 10 seconds exposure time was used, with a pixel resolution of $100 \mu \mathrm{m}$.

\section{Results}

\subsection{Water mapping in through-flow mode}

Figure 2 shows the water distribution when operating in through-flow mode after 300 s. As shown previously [57], water accumulates under the lands of the cathode flow field (corresponding to the cooling channel region), where the flow of air does not have the same dehydrating effect as in the active channels. Liquid water within the membrane is beneficial to the cell, as it ensures proton conductivity, given that the water content does not cause saturation and flooding. 


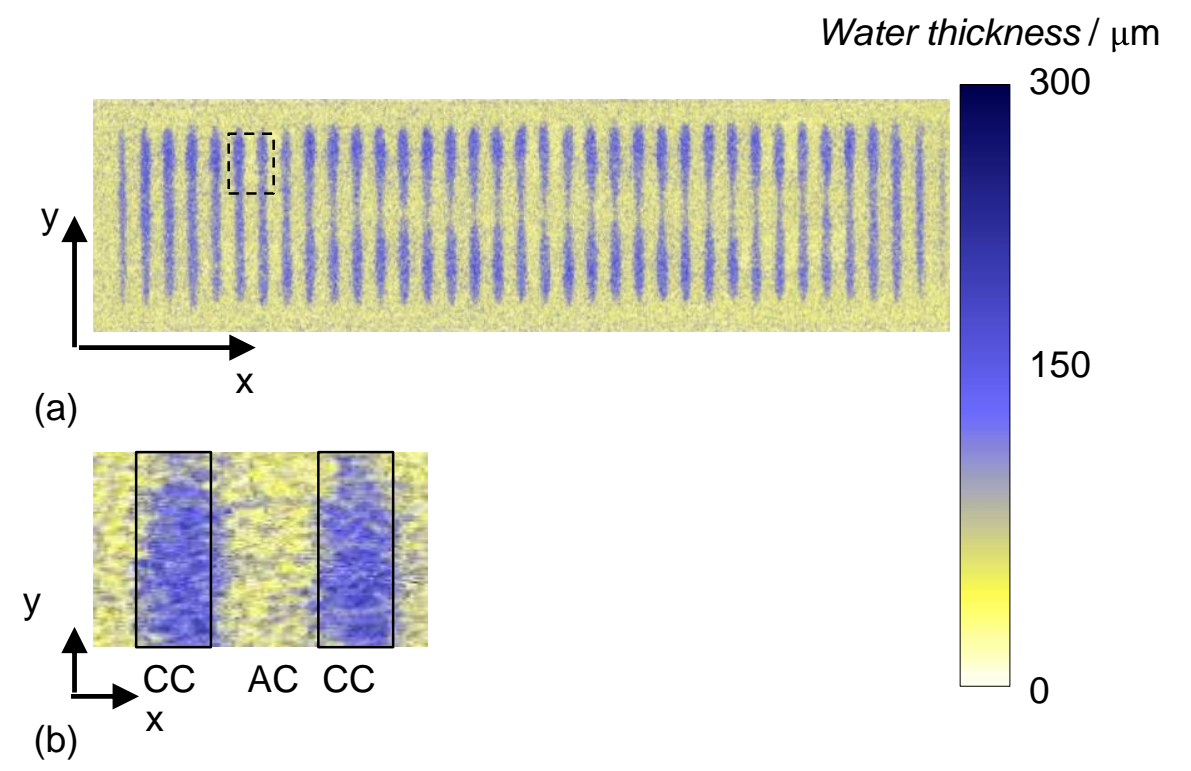

Figure 2. Water maps obtained using neutron imaging in through-flow at $0.53 \mathrm{~A} \mathrm{~cm}^{-2}$. (a) Entire cell, and close up view (b). AC: active channels. CC: cooling channels

\subsection{Dead-ended anode performance.}

Previous dead-ended investigations, on the same stack architecture, revealed that voltage decay in dead-ended anode mode becomes significant above $0.45 \mathrm{~A} \mathrm{~cm}^{-2}$ [29]. Figure 3 shows the polarisation curve in through-flow mode and how the voltage degrades (and cell temperature increases) with time for a cell operated in dead-ended mode with an average current density of $0.53 \mathrm{~A} \mathrm{~cm}^{-2}$. This corresponds to the current of lowest resistance (CLR), investigated using low frequency impedance over the entire polarisation in previous work, corresponding current density for which the low frequency impedance reaches a minimum [57]. The current of lowest resistance represents a rational choice of fuel cell operating point, with a sensible trade of between performance and efficiency, in the absence of other considerations [57]. 

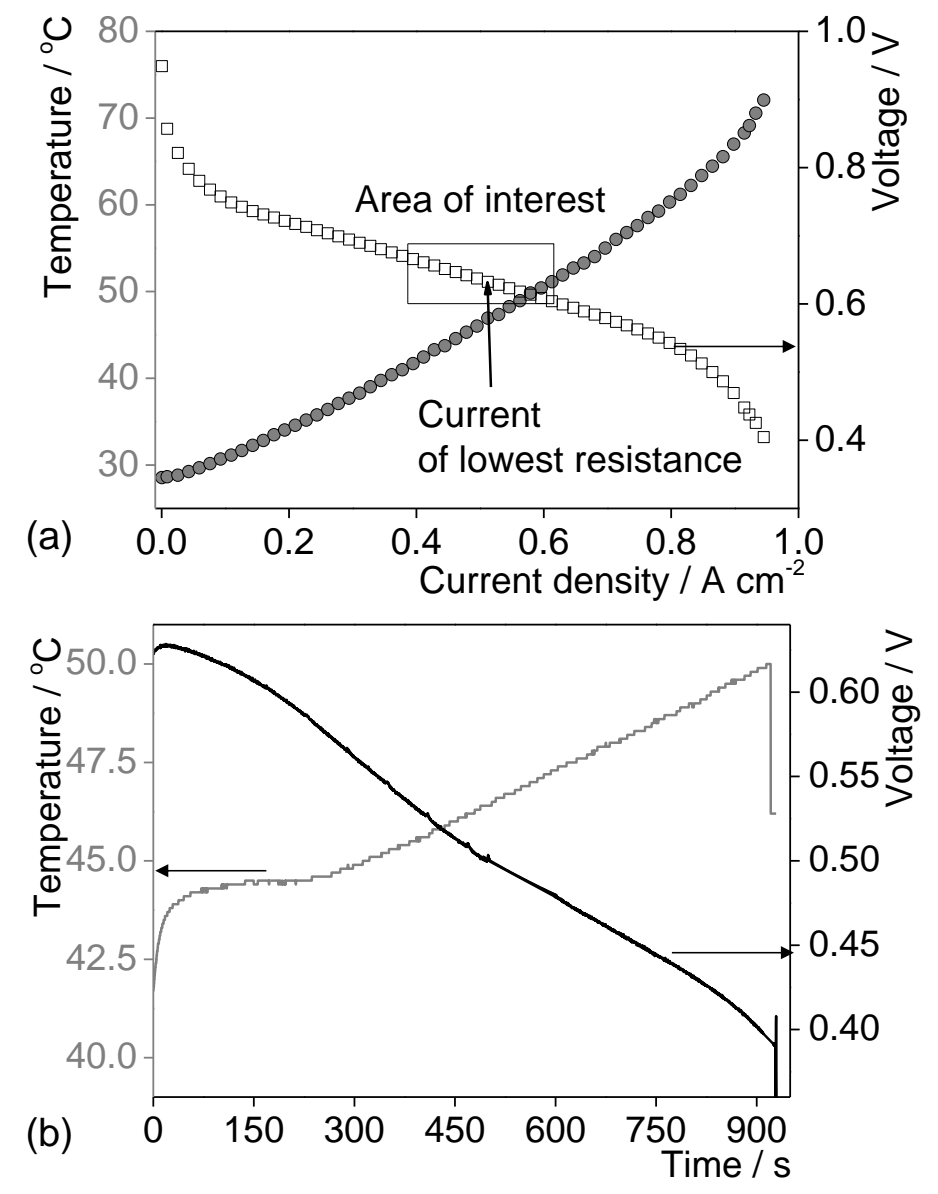

Figure 3. (a) Voltage and temperature versus current density during through-flow operation; (b) voltage decay and temperature increase over $930 \mathrm{~s}$ in dead-ended anode mode at 0.53 $\mathrm{A} \mathrm{cm}{ }^{-2}$.

The exhaust valve was kept closed until the voltage drops below $0.4 \mathrm{~V}$ (duration: 930 s). The observed cell temperature increase of $7.5^{\circ} \mathrm{C}$ is consistent with previous studies $[29,57]$.

Figure 4 shows how the water distribution evolves with time: initially, in through-flow, the water content is uniformly distributed across the extent of the cell under the land positions. On entering dead-ended operation, the centre of the cell gradually dehydrates with increasing time. The dry region in the centre eventually covers $60 \%$ of the cell area after $930 \mathrm{~s}$. 
After $420 \mathrm{~s}$ the substantial dehydration in the centre is combined with an increase of hydration at the edges of the cell. It is noticeable that at the edges of the electrode, even the active channel areas start to hydrate, which usually remain dry. On the last image at $900 \mathrm{~s}$, the amount of water at the edges has reduced compared to $420 \mathrm{~s}$, while the central dry region covers over $60 \%$ of the electrode area.

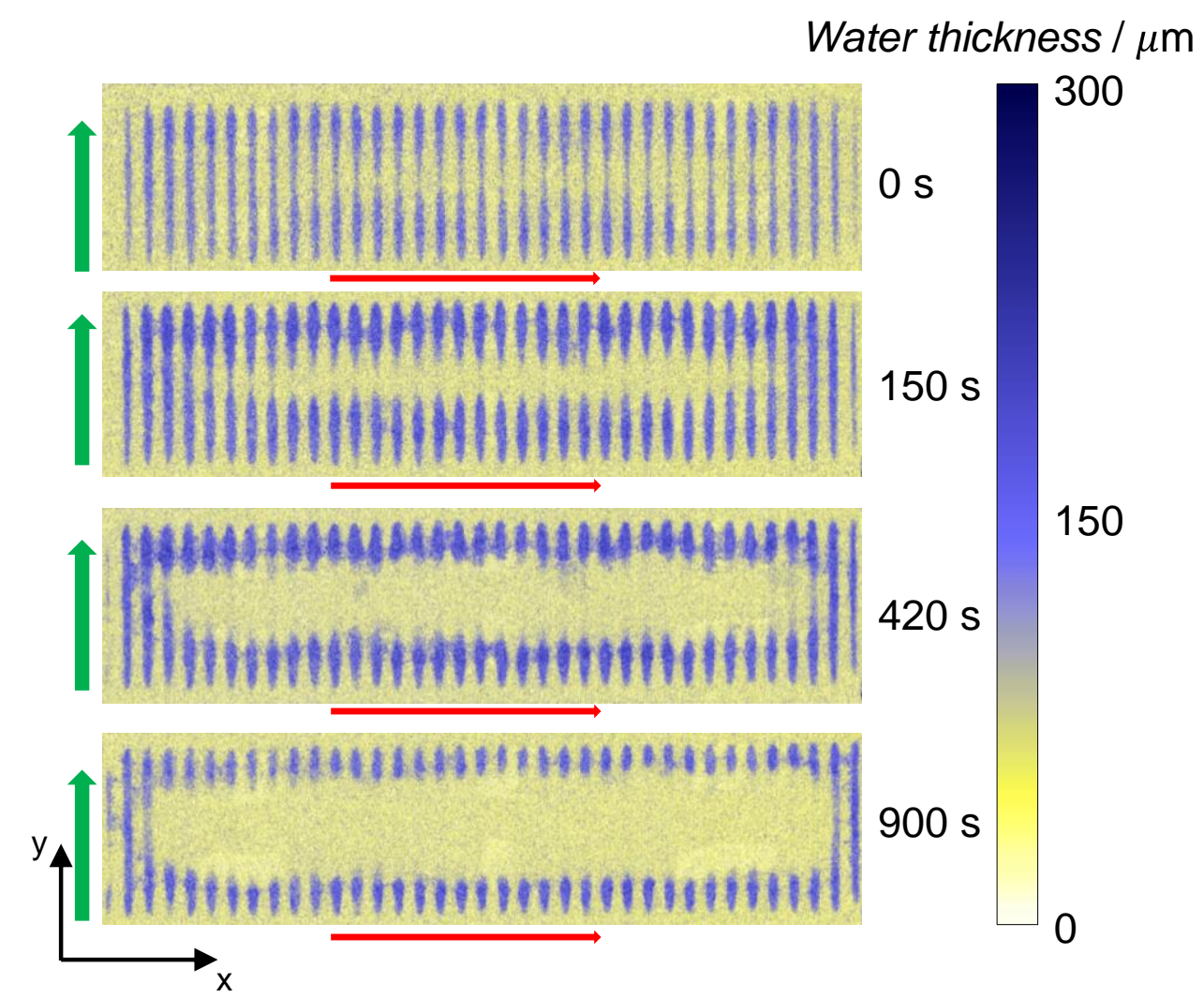

Figure 4. Hydrographs of the entire cell after $0 \mathrm{~s}, 150 \mathrm{~s}, 420 \mathrm{~s}$ and $900 \mathrm{~s}$ in dead-ended anode mode. The red arrow indicates the nominal hydrogen flow direction and green arrow the air flow direction.

The factors that influence water, temperature and reaction distribution in fuel cells are complex and highly coupled; the dehydration observed at the centre of the cell can have multiple explanations. Firstly, the dry region in the centre of the cell could be caused by nitrogen blanketing ( $\mathrm{N}_{2}$ cross-over from the cathode), shielding the 
electrode from $\mathrm{H}_{2}$ access and creating fuel depletion in that region. Detection of a build-up of $\mathrm{N}_{2}$ at the anode for an equivalent stack technology has been reported previously [29]. Reports on other stack technologies operating in dead-ended mode show that $\mathrm{N}_{2}$ concentrations rising to $60-80 \%$ over $900 \mathrm{~s}$ can occur $[84,85]$. Thermal effects can also lead to dehydration: overheating in dead-ended mode has previously been reported at higher load [33] and could lead to cell dehydration in this fuel cell technology for an average cell temperature higher than $55^{\circ} \mathrm{C}$ [57].

To the authors' knowledge, this is the first time that dehydration at the centre of a cell has been observed in dead-ended anode operation. In order to ascertain the reason and mechanism of the effect, a correlative metrology approach is described here that combines local mapping of water distribution, current density and temperature in a 'hydro-electro-thermal' analysis.

\subsubsection{Hydro-electro-thermal analysis.}

The neutron images have been processed with ImageJ to provide average sector water content over 16 segments for comparison with the information captured by the 16 segment current and temperature mapping sensor plate. Supplementary Figure S1 provides the detailed individual trends for each segment with time. However, by considering separate maps of water, current and temperature at several discrete areas in time (Figure 5, Figure 6) it is possible to appreciate the main trends observed.

Initial through-flow conditions show relatively homogeneous distributions of each quantity, with the map at $0 \mathrm{~s}$ showing the water profile, current density and temperature profile (Figure $5 \mathrm{a}, \mathrm{c}, \mathrm{e}$ ), or hydro-electro-thermal map. General trends that have been reported previously [57] include the small decrease in current density 
from hydrogen inlet to outlet, associated with hydrogen consumption in the direction of flow; and cell temperature increase from air inlet to exit, associated with the cooling effect of ambient air entering the stack. The water content initially increases in the centre of the cell until $150 \mathrm{~s}$ (Figure S1, a, b), this is consistent with the fact that water cannot be expelled from the anode during dead-ended mode, so initially more prone to water build-up. The temperature profile does not change substantially during this period. At $150 \mathrm{~s}$, the water content is slightly higher toward the edges than the centre $(3 \mu \mathrm{m})$, whereas the centre of the cell does not have the highest current density and temperature, with a shift towards the air exhaust (Figure $5 \mathrm{~b}-\mathrm{d}-\mathrm{f}$ ).

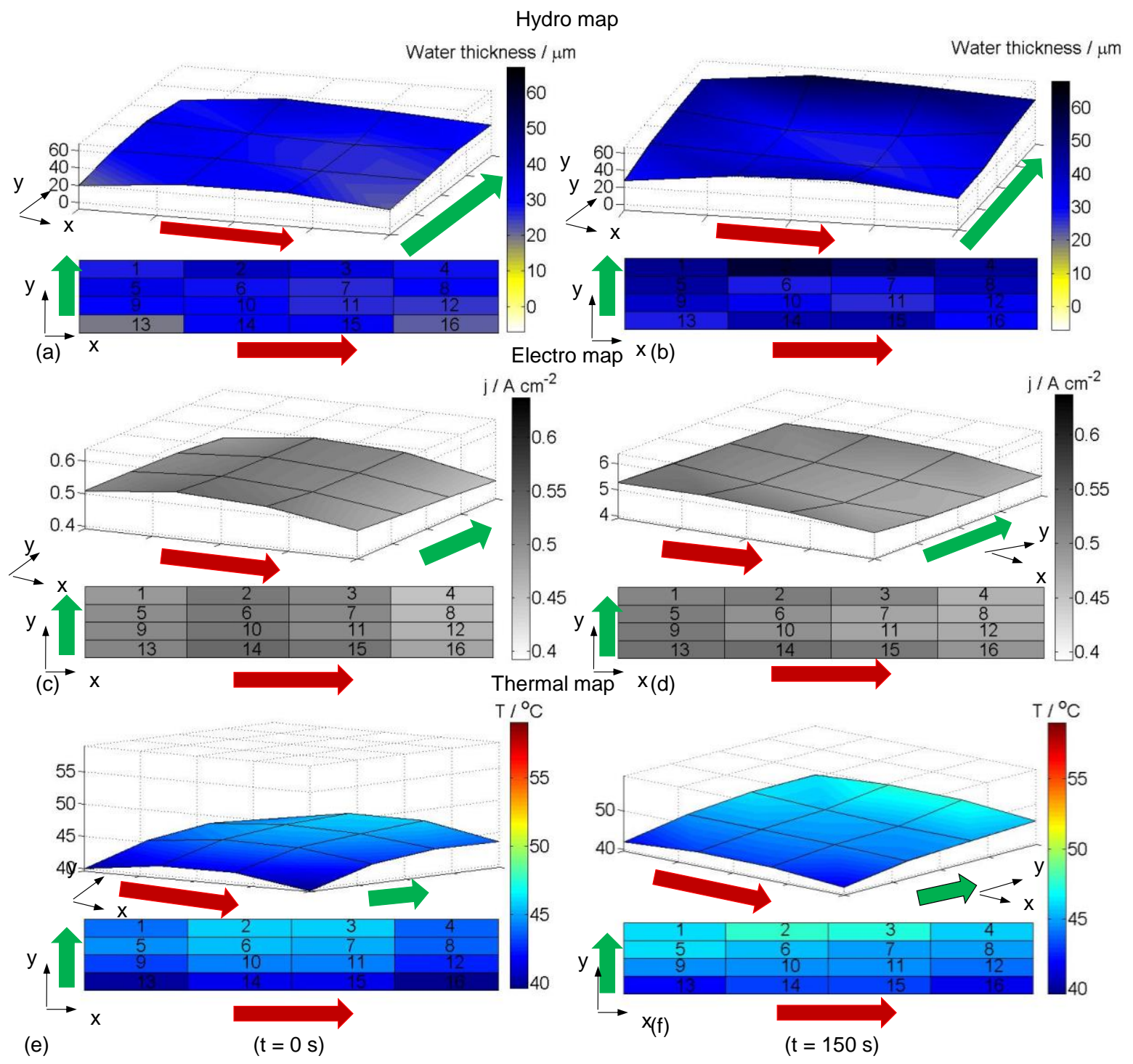


Figure 5. Hydro-electro-thermal profiles at initial conditions in through-flow (a-c-e) and after $150 \mathrm{~s}$ in dead-ended anode (b-d-f). The red arrow indicates the nominal hydrogen flow direction and the green arrow indicates the air flow direction. Average current density: $0.53 \mathrm{~A}$ $\mathrm{cm}^{-2}$.

After $150 \mathrm{~s}$, the centre of the cell (segments 6, 7, 10, 11) dehydrates, which also coincides with the continuous decay of the current density of the central segments (Figure $\mathrm{S} 1 \mathrm{~b}-\mathrm{d}$ ). As the system is operated galvanostatically, the total current remains constant and consequently the current density around the edges of the cell increases to account for the reduction in current from the centre of the cell. Between 150 and $420 \mathrm{~s}$, the temperature around the perimeter increases by $\sim 7^{\circ} \mathrm{C}$, but by only $\sim 2{ }^{\circ} \mathrm{C}$ in the centre (Figure S1). At $420 \mathrm{~s}$, the centre is $7 \mu \mathrm{m}$ drier, combined with a current density and temperature $46 \mathrm{~mA} \mathrm{~cm}^{-2}$ and $1.8^{\circ} \mathrm{C}$ lower at the centre than the edges, altogether indicative of a less active reaction zone (Figure 6 a-c-e). It is known that the central area temperature $\left(45-47^{\circ} \mathrm{C}\right)$ is not high enough to dehydrate the membrane [57], and it is observed that areas around the perimeter are hotter $\left(47-51^{\circ} \mathrm{C}\right)$ and remain hydrated. It therefore follows that the reduced central current is a consequence of reactant starvation caused by accumulation of nitrogen that has crossed-over from the cathode which results in lower water content as a result of lack of reaction and not due to dehydration caused by elevated temperature.

From $420 \mathrm{~s}$ to $900 \mathrm{~s}$, the water content in the centre reduces further, but also diminishes around the periphery due to increasing temperature $\left(50-59^{\circ} \mathrm{C}\right)$ caused by high local current density (Figure S1). At $900 \mathrm{~s}$, the cell is almost completely dry (water thickness $<5 \mu \mathrm{m}$ ) whereas the current density and temperature are respectively $84 \mathrm{~mA} \mathrm{~cm}^{-2}$ and $3.1^{\circ} \mathrm{C}$ lower at the centre than the edges (Figure $6 \mathrm{a}-\mathrm{C}-$ e). It is known that in these systems, which have very high cathode flow rates and 
use unhumidified gases, operation above $\sim 50{ }^{\circ} \mathrm{C}$ results in membrane dehydration due to enhanced evaporation at the cathode [57]. Therefore, the cell continues to reduce in voltage due to a combination of dehydration and fuel starvation caused by $\mathrm{N}_{2}$ crossover.

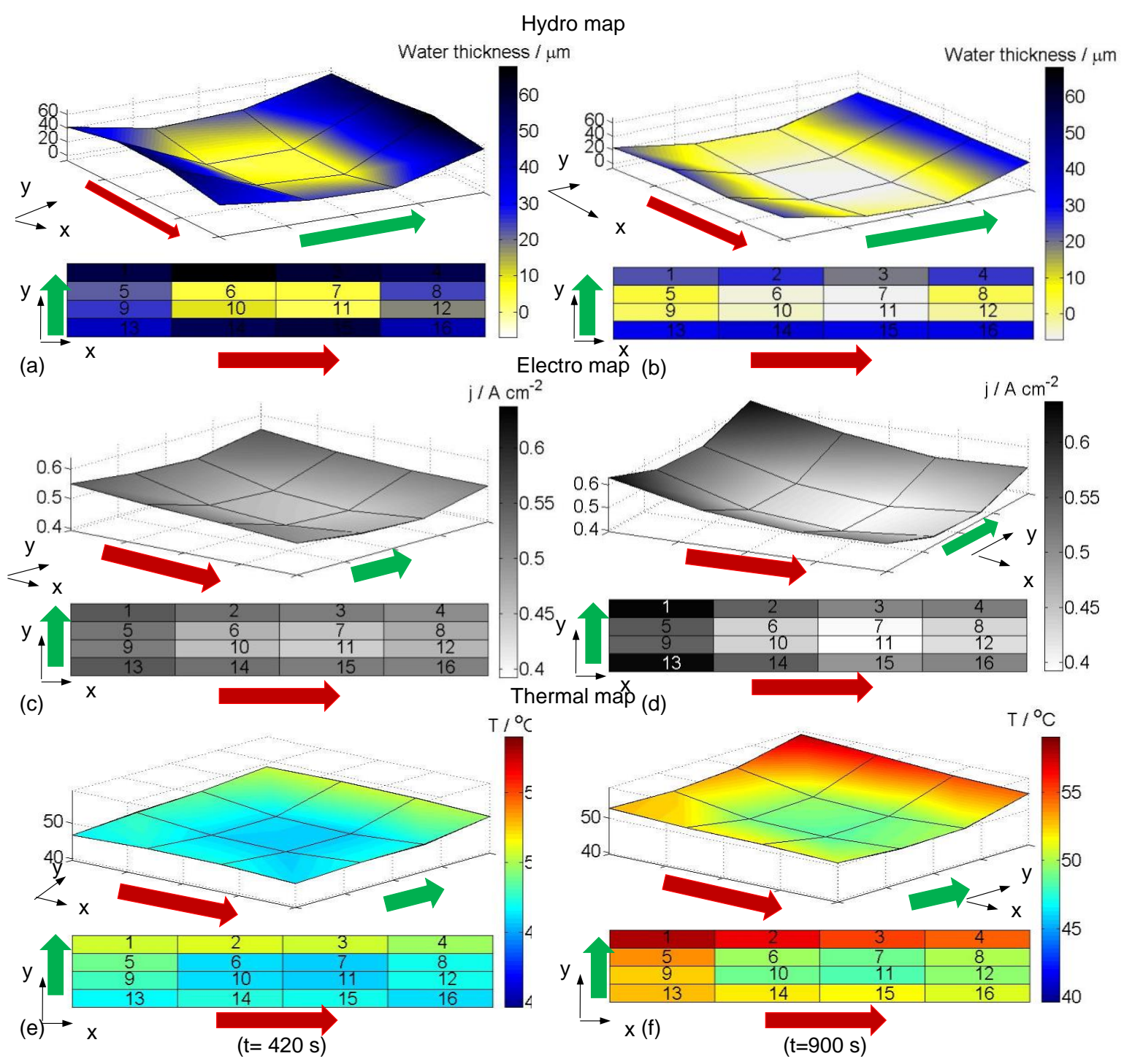

Figure 6. Hydro-electro-thermal profiles after $420 \mathrm{~s}(\mathrm{a}-\mathrm{c}-\mathrm{e})$ and after $900 \mathrm{~s}$ in dead-ended anode (b-d-f). The red arrow indicates the nominal hydrogen flow direction and the green arrow indicates the air flow direction. Average current density: $0.53 \mathrm{~A} \mathrm{~cm}^{-2}$. 
In dead-ended mode, $\mathrm{H}_{2}$ is constantly supplied to the anode but there is no macroscopic flow through the chamber towards an outlet. Consequently, any $\mathrm{N}_{2}$ crossing over from the cathode has no means of escaping and will tend to accumulate in the anode. The way in which the current density retracts from the centre of the cell and intensifies around the edges is a consequence of a design feature of many fuel cells. There is typically a very small gap between the GDL and gasket in a cell; this is due to limitations in the dimensional tolerance of components when assembled. This gap will not cause a leak as the cell is sealed by the gaskets. In through-flow, this gap does not affect performance as the hydrogen propagates in the entire anodic compartment, as there is a convective flux from the hydrogen inlet to the exhaust. On the other hand, in dead-ended, as the flow is built up by diffusion, this gap provides a by-pass route, or pathway of least resistance, for $\mathrm{H}_{2}$ to access the electrode around the perimeter of the GDL (Figure 7).This analysis, supported by the current and temperature mapping, is in agreement with the investigation carried out by Stahl et al. [37], whereby the edge channel was interrupted in order to create a local bypass causing a localised redistribution of water. Here, a similar feature is observed, on a large scale non-humidified 2-cell stack, operated in dead-ended anode, with redistribution occurring over the entire cell area. These findings have important consequences for stack / cell design, and has to be taken into further consideration for fuel cell engineering. 


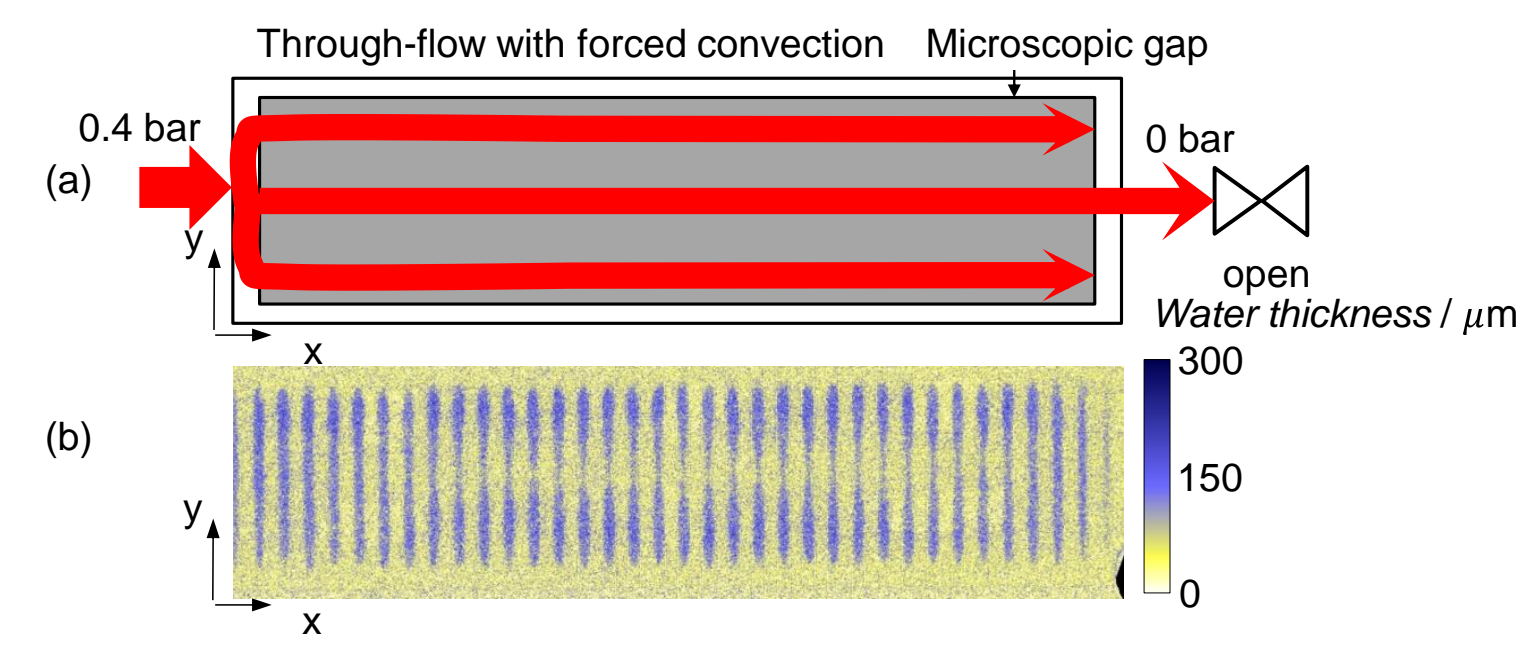

Dead-Ended with nitrogen blanketing and fuel depletion hypothesis
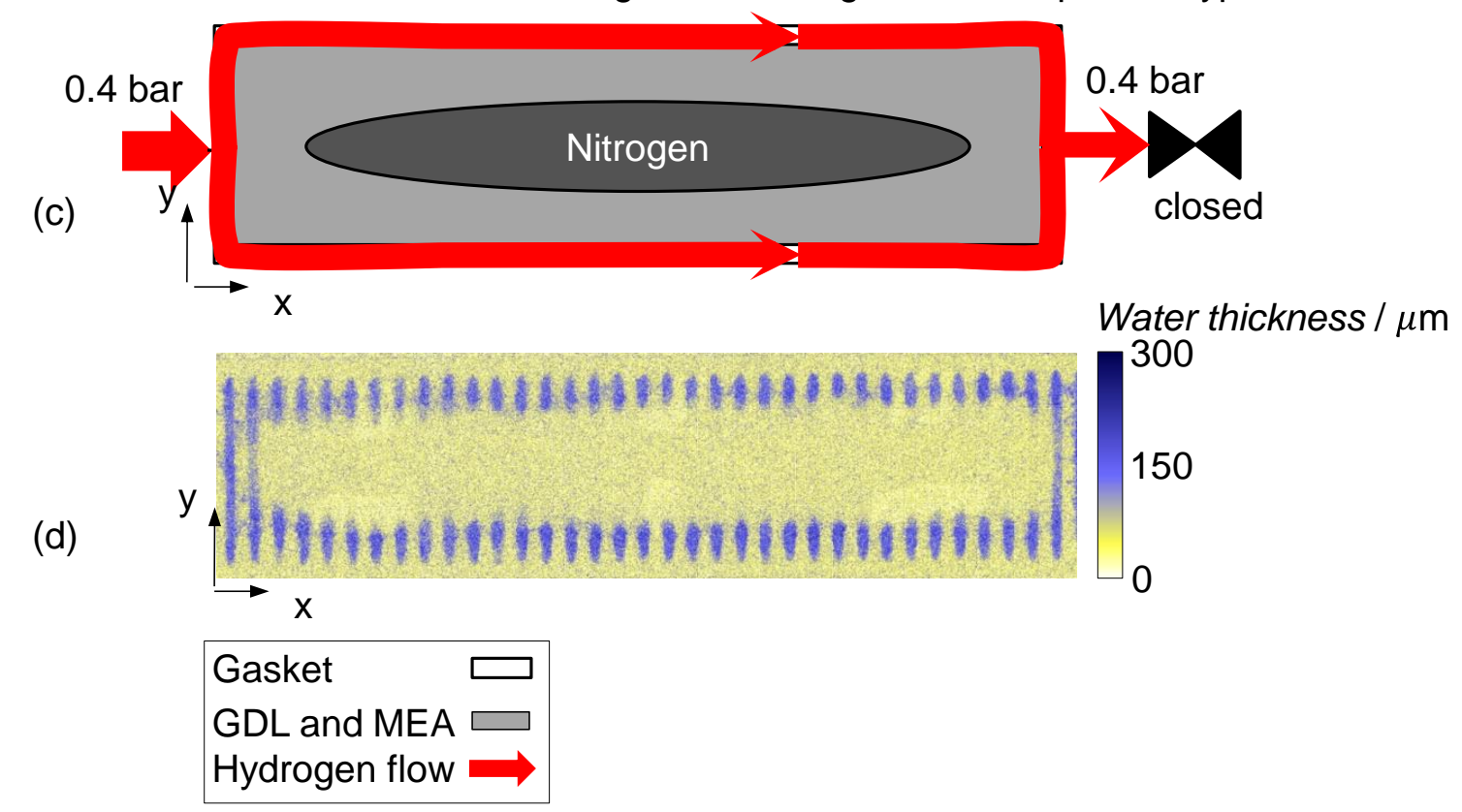

Figure 7. Flow patterns in through flow (a), and corresponding neutron image (b) and dead ended anode hypotheses: nitrogen accumulation and fuel depletion (c), corresponding neutron image (d) in a rectangular GDL without forced convection, with inlet hydrogen pressure of 0.4 bar.

\section{Conclusion}

Operation of air-cooled open-cathode fuel cells in dead-ended mode with intermittent purge has a number of practical advantages; however, greater understanding of the mechanism that leads to reversible performance degradation in the dead-end period 
is required. Here a combined hydro-electro-thermal analysis has shown that the cell performance limitation in dead-ended anode is initially caused by a lower water content, current density and temperature at the centre of the cell. This is attributed to $\mathrm{N}_{2}$ blanketing the electrode and $\mathrm{H}_{2}$ accessing the electrode around the periphery due to the small gap between the GDL and gasket that allows a gas bypass to access the edges of the GDL. As a consequence, since a constant load is applied, high local current density at the edges of the cell results in increased temperature and further dehydration of the membrane.

This may affect the efficacy of dead-ended mode of operation as the very high current densities at elevated temperatures around the periphery may have operational and durability consequences. While this result is specific to this particular type of fuel cell, there are also consequences for conventional cells where the 'fringe flow' feature should be considered as an integral part of the flow-field. For example, these features could become manifest when water obstructs a flow field channel, the flow field has been improperly designed or the gasket has been misaligned.

\section{Acknowledgements}

The authors would like to acknowledge the EPSRC for supporting the Electrochemical Innovation Lab through (EP/M009394/1, EP/G030995/1, EP/I037024/1, EP/M014371/1 and EP/M023508/1). The authors acknowledge the support of Intelligent Energy and UCL for supporting the studentship of Meyer and the RAEng for supporting Shearing. The neutron imaging work was carried out with the support of the European Community. The authors appreciate the support of the European Research Infrastructure H2FC (funded under the FP7 specific programme Capacities, Grant Agreement Number 284522) and its partner PSI. Financial support 
by the Austrian Ministry of Transport, Innovation and Technology (BMVIT) and The Austrian Research Promotion Agency (FFG) is gratefully acknowledged for the funding of the A3FALCON Project. We also thank Dr Denis Kramer for many useful discussions.

\section{References}

[1] P. Moçotéguy, F. Druart, Y. Bultel, S. Besse, A. Rakotondrainibe, Monodimensional modeling and experimental study of the dynamic behavior of proton exchange membrane fuel cell stack operating in dead-end mode, J. Power Sources. 167 (2007) 349-357. doi:10.1016/j.jpowsour.2007.02.028.

[2] S.J.C. Cleghorn, C.R. Derouin, A printed circuit board approach to measuring current distribution in a fuel cell, J. Appl. Electrochem. 28 (1998) 663-672.

[3] D.J.L. Brett, S. Atkins, N.P. Brandon, V. Vesovic, N. Vasileiadis, A.R. Kucernak, Measurement of the current distribution along a single flow channel of a solid polymer fuel cell, Electrochem. Commun. 3 (2001) 628-632.

[4] D. Gerteisen, W. Mérida, T. Kurz, P. Lupotto, M. Schwager, C. Hebling, Spatially Resolved Voltage, Current and Electrochemical Impedance Spectroscopy Measurements, Fuel Cells. 11 (2011) 339-349. doi:10.1002/fuce.201000181.

[5] I. Alaefour, G. Karimi, K. Jiao, S. Al Shakhshir, X. Li, Experimental study on the effect of reactant flow arrangements on the current distribution in proton exchange membrane fuel cells, Electrochim. Acta. 56 (2011) 2591-2598. doi:10.1016/j.electacta.2010.11.002.

[6] J. Kleemann, F. Finsterwalder, W. Tillmetz, Characterisation of mechanical behaviour and coupled electrical properties of polymer electrolyte membrane fuel cell gas diffusion layers, J. Power Sources. 190 (2009) 92-102. doi:10.1016/j.jpowsour.2008.09.026.

[7] D.J.L. Brett, S. Atkins, N.P. Brandon, N. Vasileiadis, V. Vesovic, A.R. Kucernak, Membrane resistance and current distribution measurements under various operating conditions in a polymer electrolyte fuel cell, J. Power Sources. 172 (2007) 2-13. doi:10.1016/j.jpowsour.2007.05.071.

[8] M. Santis, S.A. Freunberger, M. Papra, A. Wokaun, N.B. Felix, Experimental investigation of coupling phenomena in polymer electrolyte fuel cell stacks, J. Power Sources. 161 (2006) 1076-1083. doi:10.1016/j.jpowsour.2006.06.007.

[9] D. Gerteisen, N. Zamel, C. Sadeler, F. Geiger, V. Ludwig, C. Hebling, Effect of operating conditions on current density distribution and high frequency resistance in a segmented PEM fuel cell, Int. J. Hydrogen Energy. 37 (2012) 7736-7744. doi:10.1016/j.ijhydene.2012.02.024.

[10] M.M. Mench, C.Y. Wang, M. Ishikawa, In Situ Current Distribution Measurements in Polymer Electrolyte Fuel Cells, J. Electrochem. Soc. 150 (2003) A1052-A1059. doi:10.1149/1.1584440. 
[11] J.J. Hwnag, W.R. Chang, R.G. Peng, P.Y. Chen, A. Su, Experimental and numerical studies of local current mapping on a PEM fuel cell, Int. J. Hydrogen Energy. 33 (2008) 5718-5727. doi:10.1016/j.ijhydene.2008.07.035.

[12] Y. Yu, X.-Z. Yuan, H. Li, E. Gu, H. Wang, G. Wang, et al., Current mapping of a proton exchange membrane fuel cell with a segmented current collector during the gas starvation and shutdown processes, Int. J. Hydrogen Energy. 37 (2012) 15288-15300. doi:10.1016/j.ijhydene.2012.07.023.

[13] I. Alaefour, G. Karimi, K. Jiao, X. Li, Measurement of current distribution in a proton exchange membrane fuel cell with various flow arrangements - A parametric study, Appl. Energy. 93 (2012) 80-89. doi:10.1016/j.apenergy.2011.05.033.

[14] F.N. Büchi, A.B. Geiger, R.P. Neto, Dependence of current distribution on water management in PEFC of technical size, J. Power Sources. 145 (2005) 62-67. doi:10.1016/j.jpowsour.2004.12.039.

[15] M. Wilkinson, M. Blanco, E. Gu, J.J. Martin, D.P. Wilkinson, J.J. Zhang, et al., In Situ Experimental Technique for Measurement of Temperature and Current Distribution in Proton Exchange Membrane Fuel Cells, Fuel Cell. 9 (2006) 507-511. doi:10.1149/1.2338769.

[16] M. Matian, A. Marquis, D. Brett, N. Brandon, An experimentally validated heat transfer model for thermal management design in polymer electrolyte membrane fuel cells, Proc. Inst. Mech. Eng. Part A J. Power Energy. 224 (2010) 1069-1081. doi:10.1243/09576509JPE1011.

[17] G. Zhang, L. Guo, L. Ma, H. Liu, Simultaneous measurement of current and temperature distributions in a proton exchange membrane fuel cell, J. Power Sources. 195 (2010) 3597-3604. doi:10.1016/j.jpowsour.2009.12.016.

[18] O. Lottin, T. Colinart, S. Chupin, S. Didierjean, A multi-instrumented polymer exchange membrane fuel cell : Observation of the in-plane non-homogeneities, J. Power Sources. 180 (2008) 748-754. doi:10.1016/j.jpowsour.2008.03.002.

[19] M. Wang, H. Guo, C. Ma, Temperature distribution on the MEA surface of a PEMFC with serpentine channel flow bed, J. Power Sources. 157 (2006) 181187. doi:10.1016/j.jpowsour.2005.08.012.

[20] A. Hakenjos, H. Muenter, U. Wittstadt, C. Hebling, A PEM fuel cell for combined measurement of current and temperature distribution, and flow field flooding, J. Power Sources. 131 (2004) 213-216. doi:10.1016/j.jpowsour.2003.11.081.

[21] L.S. Martins, J.E.F.C. Gardolinski, J.V.C. Vargas, J.C. Ordonez, S.C. Amico, M.M.C. Forte, The experimental validation of a simplified PEMFC simulation model for design and optimization purposes, Appl. Therm. Eng. 29 (2009) 3036-3048. doi:10.1016/j.applthermaleng.2009.04.002.

[22] R. Shimoi, M. Masuda, K. Fushinobu, Y. Kozawa, K. Okazaki, Visualization of the Membrane Temperature Field of a Polymer Electrolyte Fuel Cell, J. Energy Resour. Technol. 126 (2004) 258-261. doi:10.1115/1.1811119.

[23] M. Matian, A.J. Marquis, N.P. Brandon, Application of thermal imaging to validate a heat transfer model for polymer electrolyte fuel cells, Int. J. Hydrogen Energy. $\quad 35 \quad$ (2010) 12308-12316. doi:10.1016/j.jhydene.2010.08.041.

[24] D.J.L. Brett, P. Aguiar, R. Clague, a. J. Marquis, S. Schöttl, R. Simpson, et al., Application of infrared thermal imaging to the study of pellet solid oxide fuel $\begin{array}{lllll}\text { cells, J. Power } & \text { Sources. } & 166 & \text { (2007) }\end{array}$ doi:10.1016/j.jpowsour.2006.12.098. 
[25] O.A. Obeisun, Q. Meyer, J. Robinson, C.W. Gibbs, A.R. Kucernak, P. Shearing, et al., Advanced diagnostics applied to a self-breathing fuel cell O. A. Obeisun, ECS Trans. 61 (2014) 249-258.

[26] O. Obeisun, Q. Meyer, J. Robinson, C.W. Gibbs, A.R. Kucernak, P.R. Shearing, et al., Development of open-cathode polymer electrolyte fuel cells using printed circuit board flow-field plates: Flow geometry characterisation, Int. J. Hydrogen Energy. 39 (2014) 18326-18336. doi:10.1016/j.ijhydene.2014.08.106.

[27] O.A. Obeisun, Q. Meyer, E. Engebretsen, D.P. Finegan, J.B. Robinson, P.R. Shearing, et al., Effect of current density and flow plate orientation on water management in an opencathode fuel cell using thermal imaging, gravimetric analysis and water droplet visualisation, Int. J. Hydrog. Energy, Submitt. (n.d.).

[28] E. Engebretsen, J.B. Robinson, O. Obeisun, T. Mason, D. Finegan, G. Hinds, et al., Electro-thermal impedance spectroscopy applied to an open-cathode polymer electrolyte fuel cell, J. Power Sources. 302 (2016) 210-214. doi:10.1016/j.jpowsour.2015.10.047.

[29] Q. Meyer, S. Ashton, O. Curnick, T. Reisch, P. Adcock, K. Ronaszegi, et al., Dead-Ended Anode Polymer Electrolyte Fuel Cell Stack Operation Investigated using Electrochemical Impedance Spectroscopy, Off-gas Analysis and Thermal Imaging, J. Power Sources. 254 (2013) 1-9. doi:10.1016/j.jpowsour.2013.11.125.

[30] M. Noorkami, J.B. Robinson, Q. Meyer, O.A. Obeisun, E.S. Fraga, T. Reisch, et al., Effect of temperature uncertainty on polymer electrolyte fuel cell performance5, Int. J. Hydrogen Energy. 39 (2014) 1439-1448.

[31] K. Jiao, I.E. Alaefour, G. Karimi, X. Li, Simultaneous measurement of current and temperature distributions in a proton exchange membrane fuel cell during cold start processes, Electrochim. Acta. 56 (2011) 2967-2982. doi:10.1016/j.electacta.2011.01.019.

[32] A. Hakenjos, C. Hebling, Spatially resolved measurement of PEM fuel cells, J. Power Sources. 145 (2005) 307-311. doi:10.1016/j.jpowsour.2005.01.075.

[33] Q. Meyer, K. Ronaszegi, J.B. Robinson, M. Noorkami, O. Curnick, S. Ashton, et al., Combined current and temperature mapping in an air-cooled, opencathode polymer electrolyte fuel cell under steady-state and dynamic

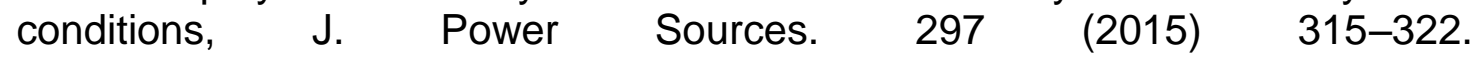
doi:10.1016/j.jpowsour.2015.07.069.

[34] Y.-S. Chen, H. Peng, D.S. Hussey, D.L. Jacobson, D.T. Tran, T. Abdel-Baset, et al., Water distribution measurement for a PEMFC through neutron radiography, J. Power Sources. $170 \quad$ (2007) 376-386. doi:10.1016/j.jpowsour.2007.03.076.

[35] M. Weiland, P. Boillat, P. Oberholzer, a. Kaestner, E.H. Lehmann, T.J. Schmidt, et al., High resolution neutron imaging for pulsed and constant load operation of passive self-breathing polymer electrolyte fuel cells, Electrochim. Acta. 87 (2013) 567-574. doi:10.1016/j.electacta.2012.09.091.

[36] P. Boillat, D. Kramer, B.C. Seyfang, G. Frei, E. Lehmann, G.G. Scherer, et al., In situ observation of the water distribution across a PEFC using high resolution neutron radiography, Electrochem. Commun. 10 (2008) 546-550. doi:10.1016/j.elecom.2008.01.018.

[37] P. Stahl, J. Biesdorf, P. Boillat, J. Kraft, K. a. Friedrich, Water Distribution Analysis in the Outer Perimeter Region of Technical PEFC Based on Neutron 
Radiography, J. Electrochem. Soc. 162 (2015) F677-F685. doi:10.1149/2.0351507jes.

[38] A. Iranzo, P. Boillat, P. Oberholzer, J. Guerra, A novel approach coupling neutron imaging and numerical modelling for the analysis of the impact of water on fuel cell performance, Energy. 68 (2014) 971-981. doi:10.1016/j.energy.2014.03.014.

[39] J. Zhang, D. Kramer, R. Shimoi, Y. Ono, E. Lehmann, A. Wokaun, et al., In situ diagnostic of two-phase flow phenomena in polymer electrolyte fuel cells by neutron imaging, Electrochim. Acta. 51 (2006) 2715-2727. doi:10.1016/j.electacta.2005.08.010.

[40] P. Oberholzer, P. Boillat, R. Siegrist, R. Perego, a. Kästner, E. Lehmann, et al., Cold-Start of a PEFC Visualized with High Resolution Dynamic In-Plane Neutron Imaging, J. Electrochem. Soc. 159 (2012) B235. doi:10.1149/2.085202jes.

[41] E.H. Lehmann, P. Boillat, G. Scherrer, G. Frei, Fuel cell studies with neutrons at the PSI's neutron imaging facilities, Nucl. Instruments Methods Phys. Res. Sect. A Accel. Spectrometers, Detect. Assoc. Equip. 605 (2009) 123-126. doi:10.1016/j.nima.2009.01.143.

[42] J.B. Siegel, D.A. McKay, A.G. Stefanopoulou, D.S. Hussey, D.L. Jacobson, Measurement of Liquid Water Accumulation in a PEMFC with Dead-Ended Anode, J. Electrochem. Soc. 155 (2008) B1168-B1178. doi:10.1149/1.2976356.

[43] D. Kramer, J. Zhang, R. Shimoi, E. Lehmann, A. Wokaun, K. Shinohara, et al., In situ diagnostic of two-phase flow phenomena in polymer electrolyte fuel cells by neutron imaging Part A. Experimental, data treatment, and quantification, Electrochim. Acta. 50 (2005) 2603-2614. doi:10.1016/j.electacta.2004.11.005.

[44] R. Satija, D.L. Jacobson, M. Arif, S. a. Werner, In situ neutron imaging technique for evaluation of water management systems in operating PEM fuel

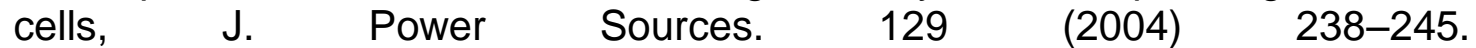
doi:10.1016/j.jpowsour.2003.11.068.

[45] I.A. Schneider, D. Kramer, A. Wokaun, G.G. Scherer, Spatially resolved characterization of PEFCs using simultaneously neutron radiography and locally resolved impedance spectroscopy, Electrochem. Commun. 7 (2005) 1393-1397. doi:10.1016/j.elecom.2005.09.017.

[46] H. Murakawa, K. Sugimoto, K. Miyata, H. Asano, N. Takenaka, Y. Saito, Visualization of Water Behavior in the In-plane and Throughplane Directions in a PEFC using a Neutron Image Intensifier, Phys. Procedia. 43 (2013) 277281. doi:10.1016/j.phpro.2013.03.032.

[47] A.B. Geiger, A. Tsukada, E. Lehmann, P. Vontobel, A. Wokaun, G.G. Scherer, In Situ Investigation of Two-Phase Flow Patterns in Flow Fields of PEFC' $s$ Using Neutron Radiography, (2002) 92-98.

[48] J.M. LaManna, S. Chakraborty, J.J. Gagliardo, M.M. Mench, Isolation of transport mechanisms in PEFCs using high resolution neutron imaging, Int. J. Hydrogen Energy. 39 (2014) 3387-3396. doi:10.1016/j.jijhydene.2013.12.021.

[49] H. Iwase, S. Koizumi, H. likura, M. Matsubayashi, D. Yamaguchi, Y. Maekawa, et al., A combined method of small-angle neutron scattering and neutron radiography to visualize water in an operating fuel cell over a wide length scale from nano to millimeter, Nucl. Instruments Methods Phys. Res. Sect. A Accel. 
Spectrometers, Detect. Assoc. Equip. 605 (2009) 95-98. doi:10.1016/j.nima.2009.01.165.

[50] N. Pekula, K. Heller, P. a. Chuang, a. Turhan, M.M. Mench, J.S. Brenizer, et al., Study of water distribution and transport in a polymer electrolyte fuel cell using neutron imaging, Nucl. Instruments Methods Phys. Res. Sect. A Accel. Spectrometers, Detect. Assoc. Equip. 542 (2005) 134-141. doi:10.1016/j.nima.2005.01.090.

[51] T.A. Trabold, J.P. Owejan, D.L. Jacobson, M. Arif, P.R. Huffman, In situ investigation of water transport in an operating PEM fuel cell using neutron radiography: Part 1 - Experimental method and serpentine flow field results, Int. J. Heat Mass Transf. 49 (2006) 4712-4720. doi:10.1016/j.jijheatmasstransfer.2006.07.003.

[52] M.A. Hickner, N.P. Siegel, K.S. Chen, D.S. Hussey, D.L. Jacobson, M. Arif, In Situ High-Resolution Neutron Radiography of Cross-Sectional Liquid Water Profiles in Proton Exchange Membrane Fuel Cells, J. Electrochem. Soc. 155 (2008) B427. doi:10.1149/1.2826287.

[53] M.A. Hickner, K.S. Chen, N.P. Siegel, Elucidating Liquid Water Distribution and Removal in an Operating Proton Exchange Membrane Fuel Cell via Neutron Radiography, J. Fuel Cell Sci. Technol. 7 (2010) 011001. doi:10.1115/1.3115624.

[54] C. Hartnig, I. Manke, N. Kardjilov, a. Hilger, M. Grünerbel, J. Kaczerowski, et al., Combined neutron radiography and locally resolved current density measurements of operating PEM fuel cells, J. Power Sources. 176 (2008) 452-459. doi:10.1016/j.jpowsour.2007.08.058.

[55] A. Iranzo, P. Boillat, F. Rosa, Validation of a three dimensional PEM fuel cell CFD model using local liquid water distributions measured with neutron imaging, Int. J. Hydrogen Energy. 39 (2014) 7089-7099. doi:10.1016/j.ijhydene.2014.02.115.

[56] D. Spernjak, S.G. Advani, A.K. Prasad, Simultaneous Neutron and Optical Imaging in PEM Fuel Cells, J. Electrochem. Soc. 156 (2009) B109. doi:10.1149/1.3009585.

[57] Q. Meyer, S. Ashton, R. Jervis, D.P. Finegan, P. Boillat, M. Cochet, et al., The Hydro-electro-thermal Performance of Air-cooled, Open-cathode Polymer Electrolyte Fuel Cells: Combined Localised Current Density, Temperature and Water Mapping, Electrochim. Acta. 180 (2015) 307-315. doi:10.1016/j.electacta.2015.08.106.

[58] J. Chen, J.B. Siegel, A.G. Stefanopoulou, J.R. Waldecker, Optimization of purge cycle for dead-ended anode fuel cell operation, Int. J. Hydrogen Energy. 38 (2013) 5092-5105.

[59] J.B. Siegel, S. V. Bohac, A.G. Stefanopoulou, S. Yesilyurt, Nitrogen Front Evolution in Purged Polymer Electrolyte Membrane Fuel Cell with Dead-Ended Anode, J. Electrochem. Soc. $157 \quad$ (2010) B1081-B1093. doi:10.1149/1.3425743.

[60] S. Yesilyurt, J.B. Siegel, A.G. Stefanopoulou, Modeling and Experiments of Voltage Transients of Polymer Electrolyte Membrane Fuel Cells With the Dead-Ended Anode, J. Fuel Cell Sci. Technol. 9 (2012) 021012. doi:10.1115/1.4005626.

[61] A.P. Sasmito, A.S. Mujumdar, Performance evaluation of a polymer electrolyte fuel cell with a dead-ended anode: A computational fluid dynamic study, Int. J. 
Hydrogen Energy. 36 (2011) 10917-10933.

[62] Y. Hou, C. Shen, Z. Yang, Y. He, A dynamic voltage model of a fuel cell stack considering the effects of hydrogen purge operation, Renew. Energy. 44 (2012) 246-251. doi:10.1016/j.renene.2012.01.088.

[63] A. Rabbani, M. Rokni, Effect of nitrogen crossover on purging strategy in PEM fuel cell systems, Appl. Energy. 111 (2013) 1061-1070. doi:10.1016/j.apenergy.2013.06.057.

[64] J. Yu, Z. Jiang, M. Hou, D. Liang, Y. Xiao, M. Dou, et al., Analysis of the behavior and degradation in proton exchange membrane fuel cells with a dead-ended anode, J. Power Sources. $246 \quad$ (2014) 90-94. doi:10.1016/j.jpowsour.2013.06.163.

[65] K.D. Baik, M.S. Kim, Characterization of nitrogen gas crossover through the membrane in proton-exchange membrane fuel cells, Int. J. Hydrogen Energy. 36 (2011) 732-739. doi:10.1016/j.ijhydene.2010.09.046.

[66] Y. Lee, B. Kim, Y. Kim, An experimental study on water transport through the membrane of a PEFC operating in the dead-end mode, Int. J. Hydrogen Energy. 34 (2009) 7768-7779. doi:10.1016/j.jhydene.2009.07.010.

[67] A. Schmitz, M. Tranitz, S. Wagner, R. Hahn, C. Hebling, Planar self-breathing fuel cells, J. Power Sources. 118 (2003) 162-171. doi:10.1016/S03787753(03)00080-6.

[68] R. Hahn, S. Wagner, A. Schmitz, H. Reichl, Development of a planar micro fuel cell with thin film and micro patterning technologies, J. Power Sources. 131 (2004) 73-78. doi:10.1016/j.jpowsour.2004.01.015.

[69] S.U. Jeong, E.A. Cho, H.-J. Kim, T.-H. Lim, I.-H. Oh, S.H. Kim, A study on cathode structure and water transport in air-breathing PEM fuel cells, J. Power Sources. 159 (2006) 1089-1094. doi:10.1016/j.jpowsour.2005.12.046.

[70] S.U. Jeong, E.A. Cho, H.-J. Kim, T.-H. Lim, I.-H. Oh, S.H. Kim, Effects of cathode open area and relative humidity on the performance of air-breathing polymer electrolyte membrane fuel cells, J. Power Sources. 158 (2006) 348353. doi:10.1016/j.jpowsour.2005.09.044.

[71] N. Bussayajarn, H. Ming, K.K. Hoong, W.Y. Ming Stephen, C.S. Hwa, Planar air breathing PEMFC with self-humidifying MEA and open cathode geometry design for portable applications, Int. J. Hydrogen Energy. 34 (2009) 77617767. doi:10.1016/j.ijhydene.2009.07.077.

[72] T. Fabian, R. O'Hayre, S. Litster, F.B. Prinz, J.G. Santiago, Passive water management at the cathode of a planar air-breathing proton exchange membrane fuel cell, J. Power Sources. 195 (2010) 3201-3206. doi:10.1016/j.jpowsour.2009.12.030.

[73] D.T.S. Rosa, D.G. Pinto, V.S. Silva, R.A. Silva, C.M. Rangel, High performance PEMFC stack with open-cathode at ambient pressure and temperature conditions, Int. J. Hydrogen Energy. 32 (2007) 4350-4357. doi:10.1016/j.jjhydene.2007.05.042.

[74] J. Wu, S. Galli, I. Lagana, A. Pozio, G. Monteleone, X. Zi, et al., An air-cooled proton exchange membrane fuel cell with combined oxidant and coolant flow, J. Power Sources. 188 (2009) 199-204. doi:10.1016/j.jpowsour.2008.11.078.

[75] G. Jung, K. Lo, A. Su, F. Weng, C. Tu, T. Yang, et al., Experimental evaluation of an ambient forced-feed air-supply PEM fuel cell, Int. J. Hydrogen Energy. 33 (2008) 2980-2985. doi:10.1016/j.jjhydene.2008.03.056.

[76] A.P. Sasmito, E. Birgersson, K.W. Lum, A.S. Mujumdar, Fan selection and 
stack design for open-cathode polymer electrolyte fuel cell stacks, Renew. Energy. 37 (2012) 325-332. doi:10.1016/j.renene.2011.06.037.

[77] B. Kim, Y. Lee, A. Woo, Y. Kim, Effects of cathode channel size and operating conditions on the performance of air-blowing PEMFCs, Appl. Energy. 111 (2013) 441-448. doi:10.1016/j.apenergy.2013.04.091.

[78] T. Fabian, J.D. Posner, R. O'Hayre, S.-W. Cha, J.K. Eaton, F.B. Prinz, et al., The role of ambient conditions on the performance of a planar, air-breathing hydrogen PEM fuel cell, J. Power Sources. 161 (2006) 168-182. doi:10.1016/j.jpowsour.2006.03.054.

[79] H. Guo, M. Hai, F. Ye, C. Fang, Experimental study of temperature distribution on anodic surface of MEA inside a PEMFC with parallel channels flow bed, Int. J. Hydrogen Energy. 37 (2012) 13155-13160. doi:10.1016/j.ijhydene.2012.03.138.

[80] C. Wen, G. Huang, Application of a thermally conductive pyrolytic graphite sheet to thermal management of a PEM fuel cell, J. Power Sources. 178 (2008) 132-140. doi:10.1016/j.jpowsour.2007.12.040.

[81] E.H. Lehmann, P. Vontobel, L. Wiezel, Properties of the radiography facility neutral at SINQ and its potential for use as European reference facility, $\begin{array}{lllll}\text { Nondestruct. } & \text { Test. } & \text { Eval. } & 16 & \text { (2001) 191-202. }\end{array}$ doi:http://dx.doi.org/10.1080/10589750108953075.

[82] P. Boillat, Advanced characterization of polymer electrolyte fuel cells using high resolution neutron imaging, ETH, 2009. doi:10.3929/ethz-a-005911827.

[83] A. Iranzo, P. Boillat, Liquid water distribution patterns featuring back-diffusion transport in a PEM fuel cell with neutron imaging, Int. J. Hydrogen Energy. 39 (2014) 17240-17245. doi:10.1016/j.ijhydene.2014.08.042.

[84] E.A. Müller, F. Kolb, L. Guzzella, A.G. Stefanopoulou, D.A. McKay, Correlating Nitrogen Accumulation With Temporal Fuel Cell Performance, J. Fuel Cell Sci. Technol. 7 (2010) 1-11. doi:10.1115/1.3177447.

[85] A. Manokaran, S. Pushpavanam, P. Sridhar, S. Pitchumani, Experimental analysis of spatio-temporal behavior of anodic dead-end mode operated polymer electrolyte fuel cell, J. Power Sources. 196 (2011) 9931-9938. doi:10.1016/j.jpowsour.2011.06.103. 


\section{Supplementary Material}
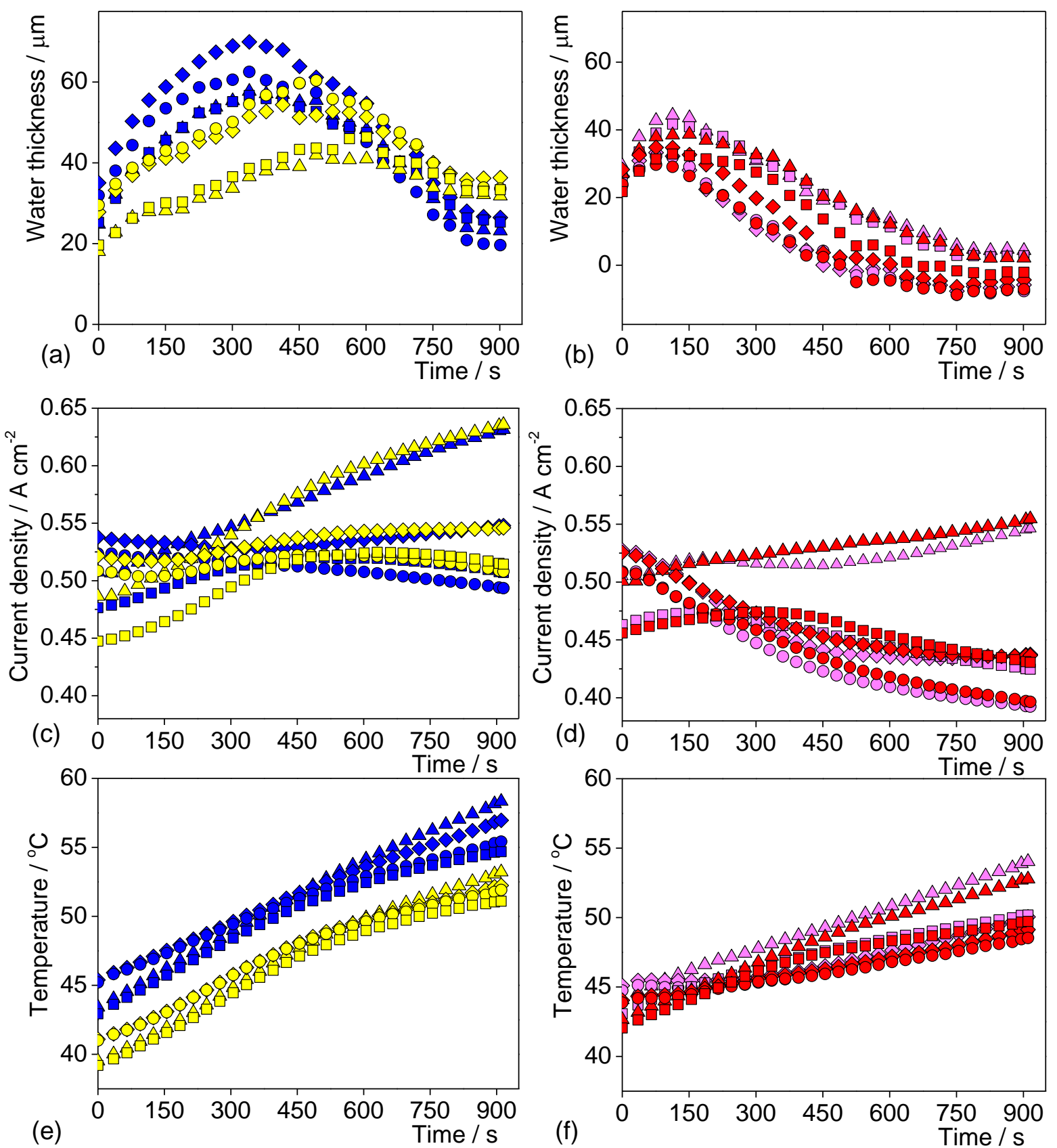

(g)

\begin{tabular}{|c|c|c|c|}
\hline $1 \Delta$ & $\gamma$ & 3 & 4 \\
\hline $5 \triangle$ & 6 & 7 & 8 \\
\hline $9 \Delta$ & $10\rangle$ & $11 \bigcirc$ & 12 \\
\hline $13 \triangle$ & $14 \diamond$ & $15 \bigcirc$ & 16 \\
\hline
\end{tabular}

Figure S1. Hydro-electro-thermal profiles describing the effect of the dead-ended event over $900 \mathrm{~s}$. The information has been divided between the $1^{\text {st }}$ and $4^{\text {th }}$ rows (a$c-e)$ and the $2^{\text {nd }}$ and $3^{\text {rd }}$ rows (b-d-f); (g) Location of the segments and corresponding colour code. 